\title{
Effectiveness of Hedging Accounting Methods:A Case of Islamic Profit Rate Swap Contract
}

\section{Ravindran Ramasamy ${ }^{1}$, Bavani Chandra Kumar ${ }^{2}$ and Zulkifflee Mohamed $^{3}$}

\author{
${ }^{1}$ Former Professor of Accounting and Finance, \\ Graduate School of Business,University Tun Abdul Razak, Malaysia. \\ ${ }^{2}$ Senior Lecturer, Tunku Abdul Rahman University College,Malaysia. \\ ${ }^{3}$ Deputy Vice Chancellor, University Tun Abdul Razak, Malaysia
}

\begin{abstract}
In this article we take a case of Islamic profit rate swap contract as hedging item and Sukuk as the hedged item to demonstrate the earnings volatility reduction under no hedging, not designated hedging, fair value hedging and cash flow hedgingmethods. Interestingly the three later heading techniques produce same earnings with same cash flows and same variation in cash flows. The 'no hedging' method shows different pattern of cash flows with lesser mean income and with more variation in income with a larger standard deviation. We suggest companies could execute 'not designated hedging' as it is not tedious in designation, valuation, treatment, effectiveness tests and less regulated. The 'not designated hedge' brings the same results as fair value and cash flow hedging methods which are more cumbersome and sensitive to effectiveness test compared to 'no hedge' method.
\end{abstract}

Key Words: Fair Value Hedging; IAS 39; Islamic Swap; Net Present Values; Sukuk;

JEL Classification: M41; M48; G32.

\section{Introduction}

In a highly uncertain Covid-19 business world presently the investments rapidly lose value creating panic among investors in capital markets. The capital market liquidity is affected as the trading actives are reduced significantly. In Malaysianeconomy two capital markets conventional and Islamic operate simultaneously issuing and trading financial assets. The institutional investors like provident fund, Tabung Haji funds and many other institutions invest heavily in financial assets in capital market. They must sustain investor confidence, by avoiding risk and maintain the values of existing portfolios at this turbulent juncture. Hedging of the investment portfolios are the need of the hour though late. Everyone in the country believes that Covid-19 will stay for longer in globe like Spanish flu during last century. Hedging is akin to insurance, where future losses are avoided by paying a small amount of premium to the indemnifier, who absorbs the losses and the indemnified is free of worries. Insurance premium is very expensive because one must insure the full value of the asset (portfolio), but cannot insure the losses.Due to this the premium for an insurance is higher. To overcome thisproblem, the derivative products (contracts) like, forward contract, futures contracts, optioncontractsand swap contractshave been issued both in conventional and under Islamic finance (Al-Suwailem, 2006; Yahya and Ahmad 2008). Thesederivative instruments are guaranteed contracts, follow rules and highly regulated by various agencies in every economy and by every country. They are safe and provide a mechanism to protect portfolios and avoid losses with a small premium, payable to the dealers or writers of these contracts (Abken, 1993). The derivative products accomplishrisk management through hedge accounting effectively (Brown, K, Harlow and Smith, 1994; Kijima and Muromachi, 2001). 


\section{International accounting standard 39 (IAS 39)}

Enron company failure brought several accounting issues to the fore and showed the weaknesses of historical cost accounting especially in the financial commitments and the derivatives as they do not have value at inception. Only as foot notes they were stated as additional information. The Sarbanes Oxley Act of 2002 passed by American Parliament made life difficult to accountants as it proposed fair value accounting for all financial investments and commitments whether it is primary product or derivative instrument. All are to be fair valued and resultant profit or loss is to be immediately expensed in income statement. The fair values are to be reported in financial position statement. This is a radical deviation from the historical cost accounting methods and there was a big hue and cry that it will increase the volatility of income reported thereby it will affect earnings per share and consequently volatile share prices, which is not good for the company and capital market. To suppress this criticism, the accounting bodies suggested risk management to reduce the volatility in earnings and proposed hedge accounting with certain conditions. Three hedge accounting techniques namely fair value, cash flow and net investment in a foreign operation were proposed. The IAS 39 accounting treatment is also applicable to Islamic finance in accounting.

This unexpected, under assessed Covid-19 not only affected the national GDPs all nations to varying degrees but also the capital markets and employment markets. The daily wage earners and small business people and unorganised sector workers are the severely affectedas they lost daily earnings. The main sectors of economy such as tourism, star hotels, airline industry registeredalmost zero revenue during the last three months and still their operation is uncertain. Many other sectors which depend on tourism are affected indirectly. The ultimate effect is felt in capital market which is detrimental to the investors. This volatility could be managed effectively through derivative contracts. Presently,more and more companies and financial institutions and institutional investors manage theirvalues of their portfolios and financial investments through derivatives, which is collectively addressed as hedging.

This article demonstrates the accounting treatments of various hedging methods and their effects on income volatility, tax effect and ultimately how the cash flow changes when the derivative contracts are used to mitigate the losses through hedging and how they affect the income volatility.

\section{Coupon rate and yield rate an islamic perspective}

Coupon rate is the rate promised by the borrower to the lender at the time of raising finance and will be paid regularly throughout the life of the debt till maturity. This coupon rate is called as profit rate in Islamic Finance (Bacha, 2007; Woodhead,2009). It is useful only to compute the regular cash outflows in the form of interest or profit. In the historical cost accounting it plays significant role. But in the fair value accounting the coupon rate lost its importance and it is taken over by the yield rate. This yield rate is market determined by numerous factors prevailing in the market. This yield rate determines the value of any item usually by discounting the cash flows for the remaining period of life till maturity. The ups and downs in the value are to be expensed immediately without deferring in income statement. The updated value (amortised cost) is to be shown in the financial position statement. Coupon rate is useful in calculating regular cash flows while the yield rate is useful in valuing the assets and liabilities. Coupon rate is fixed and constant till maturity but the yield rate is dynamic and changing on daily basis like exchange rates and share prices. Yield rate and the value are negatively correlated. When yield rate goes up assets lose value and liabilities gain in value and vice versa. When assets lose value investors are worried and when liabilities increase in value the borrowers are worried because they have to repay more. This is the main reason for risk management and effected through hedge accounting.

\section{Hedging}

Financial assets, unlike other assets, are easily prone to value changes whenever the market yield rate changes. The yield rate and the value of financial assets have negative relationship. If yield rate goes up the financial asset will fall in value (loss) and financial liability will gain in value (profit) and vice versa. The market yield rate is dynamic and changes based on economic conditions and also due to demand and supply of funds in the interbank market. This value drop and gain are to be recorded in income statement immediately as per IAS 39. This creates volatility in income. Market uses this volatility (standard deviation) in option valuation, lending rate forecasting and in many financial decisions. A higher volatility is associated with more cost of borrowing and more risk. This volatility could be reduced by selecting a matching derivative contract which will act diametrically opposite to the financial asset (underlying). The above principle and mechanism are also applicable to Islamic Finance. 
If the asset is in long position the derivative should be in short position and vice versa. In the long position when the price of the hedged item increases, profit is generated and in the short position to the same extent loss is generatedby the derivative product. If added together theyoffset each other and the volatility in income is reduced. This process is less expensive when compared to insurance premium. These derivative contracts are sold practically at zero value. While the financial commitment or investment or liabilities are large amounts but the derivatives are purchased for a paltry sum like margin money and stamp duty etc. Practically they have zero value at inception.

The underlying's price and the derivative price will move in the same direction. There are two derivative contractsexist (long and short) for every underlying asset. One contract gives the right to buy the underlying at current price but at a future dateand the other contract gives the right to sellthe underlying at current price at a future date. When a company owns aportfolio already (invested in financial assets) must shortderivative contracts and vice versa. In other words, a long in investments should be matched with a short in derivatives and vice versa.

\section{Hedged Items}

Any item whose value is to be protected from price fall is an underlyingwhose price is dynamic and highly volatile. If no action is taken the fluctuating prices will cause significant distortion in earnings. Examples include all types of inventories like, crude oil, palm kernel, palm oil, etc whose prices are not stable as the market conditions vary on daily basis. The suppliers will be affected if the prices fall (at present covid-19) and consumers are affected if prices increase. Physical raw materials which are consumed as inputs in production, when price goes up the manufacturers are affected. These price changes affect the earnings and increase volatility in income. To reduce the losses and volatility these items are to be hedged to get stable prices. The hedging costs are insignificant; they are like insurance premium, but less than the premium as discussed earlier.

Financial assets and liabilities include shares, bonds, Sukuk, units, financial commitments, guarantees etc. The above investments will lose value at any time when the stock market goes to recession. They are highly unstable and cause volatility in income. To protect them from value, drop the investors go for derivative products. Companies raise additional finance by the issue of shares, bonds and long term borrowings. The borrowing company has to pay either fixed or floating rate payments to the fund providers which are also unstable as the market rates vary due to demand and supply of funds. The above cash flows in the form of interest or profitalso could be hedged to avoid losses at an insignificant hedging cost (Coyle, 2001).

\section{Islamic Hedge By Swap Contract - A Hypothetical Example}

IQ Berhad wanted to buy a machinery worth RM100,000 by issuing 6\% profit rate Sukuk which matures in four years from now. The machine is to be depreciated by $20 \%$ on reducing balance method; The corporate tax rate is $25 \%$. Market yield rates are expected to change from $6 \%$ to $5 \%$ in second year, to $7 \%$ in third year and to $8 \%$ in the fourth year. The company is facing cash crunch due to several ongoing projects.

IQ Bhd is concerned about the fixed profit rate and feels that if floating rate is chosen it will be cheaper and will match the cash inflows. The IQ general Manager recommendsan Islamic profit rate swap (Decovny and Christine, 1991; Das, 1994), giving up the fixed profit rate in favour of a floating rate(because he believes that in future the profit rates for Islamic Sukuk will go down). He further believes that the cash flows will also match with the Sukuk payments and the company will not face problem of default. With solid calculations under four methods of hedging he convinces everyone to go for floating rate from fixed rate. The top management still reluctant but later agrees because the manager by preparing hypothetical results under four methods no hedging, not designated hedging fair value hedging and cash flow hedging demonstrates how the losses are offset by the hedges (Marshal and Kenneth, 1990).

\section{No Hedge}

Normally if the expected yield rate movement in future is marginal in both directions any company will decide not to go for hedging as hedging involves a lot of work in the form drafting customised hedging contract, deciding intermediation fee, margin deposit etc. As it is not worth the companies would be reluctant to go for hedging. Moreover, if the amount involved is small and not significant its impact in income statement will be meagre. These are some of the reasons for not hedging assets and liabilities. This may be the reason for the company to decide not to hedge the Sukuk issue. It would be pertinent to show the journal entries and tax benefits 
the transactions would bring over the years. As such

the table one is prepared and shown below.

Table 1. Valuation and Cash Flows when no hedge is made

\begin{tabular}{|c|c|c|c|c|c|c|}
\hline & Cash & $\begin{array}{r}\text { Machine } \\
\text { Value }\end{array}$ & $\begin{array}{l}\text { Sukuk } \\
\text { Value }\end{array}$ & $\begin{array}{r}\text { Income } \\
\text { Statement }\end{array}$ & Tax savings & $\begin{array}{l}\text { Operating } \\
\text { Cash Flows }\end{array}$ \\
\hline \multicolumn{7}{|l|}{ Year 1} \\
\hline Buy machine by Sukuk & --- & 100,000 & $(100,000)$ & --- & --- & --- \\
\hline Pay Profit & $(6,000)$ & --- & --- & 6,000 & --- & --- \\
\hline \multicolumn{7}{|c|}{ Profit rate refixed at $5 \%$ on reporting date $31^{\text {st }}$ Dec } \\
\hline Revalue Sukuk & --- & --- & $(2,723)$ & 2,723 & --- & --- \\
\hline \multirow[t]{2}{*}{ Depreciation } & --- & $(20,000)$ & --- & 20,000 & --- & --- \\
\hline & $(6,000)$ & 80,000 & $(102,723)$ & 28,723 & 7,181 & $(1,542)$ \\
\hline \multicolumn{7}{|l|}{ Year 2} \\
\hline Pay Profit & $(6,000)$ & --- & 864 & 5,136 & --- & -- \\
\hline \multicolumn{7}{|c|}{ Profit rate refixed at $7 \%$ on reporting date $31^{\text {st }}$ Dec } \\
\hline Revalue Sukuk & --- & --- & 3,667 & $(3,667)$ & --- & -- \\
\hline \multirow[t]{2}{*}{ Depreciation } & -- & $(16,000)$ & --- & 16,000 & --- & --- \\
\hline & $(6,000)$ & 64,000 & $(98,192)$ & 17,469 & 4,367 & 2,898 \\
\hline \multicolumn{7}{|l|}{ Year 3} \\
\hline Pay Profit & $(6,000)$ & --- & (873) & 6,873 & --- & --- \\
\hline \multicolumn{7}{|c|}{ Profit rate refixed at $8 \%$ on reporting date $31^{\text {st }}$ Dec } \\
\hline Revalue Sukuk & --- & --- & 918 & (918) & -- & --- \\
\hline \multirow[t]{2}{*}{ Depreciation } & --- & $(12,800)$ & --- & 12,800 & --- & --- \\
\hline & $(6,000)$ & 51,200 & $(98,148)$ & 18,756 & 4,689 & $(1,267)$ \\
\hline \multicolumn{7}{|l|}{ Year 4} \\
\hline Pay Profit & $(6,000)$ & --- & $(1,852)$ & 7,852 & --- & --- \\
\hline Depreciation & --- & $(10,240)$ & --- & 10,240 & --- & --- \\
\hline \multirow[t]{2}{*}{ Settle all } & $(100,000)$ & --- & 100,000 & --- & --- & -- \\
\hline & $(106,000)$ & 40,960 & - & 18,092 & 4,523 & $(3,329)$ \\
\hline
\end{tabular}

Each row is a journal entry. Figures in parenthesis are credit balances.

Column two shows the cash out flows over the life of four years. The company has to pay a profit of 6,000 to Sukuk investors and in the final year the amount of Sukuk is to be returned to the investors. The machinery purchased would be depreciated at a rate of $20 \%$ on diminishing value method and the depreciations will be expensed in income statement. The balance after depreciation would be shown in the financial position statement.

The Sukuk is to be valued at every reporting date and should be shown in financial position statement at fair value (IAS 39). The valuation technique is the standard present value calculation at the prevailing market yield rate. The yield rates change from $6 \%$ to $5 \%, 7 \%$ and $8 \%$ over the years these rates are applied to compute the value of Sukuk at every reporting date. Any appreciation or fall is to be expensed immediately in income statement. The values are given in the fourth column. The income statement is given in the fifth column with debit and credit amounts. Amounts appear in parenthesis are credit balances meaning that they are profits and vice versa. At the reporting date they are added and net balance is arrived and tax is computed and shown in the next column. The tax balances are tax savings not payable because income statement shows debit balances in all years. The final column shows the operating cash flows due to the machinery and Sukuk. If depreciation is added to the profit after tax it is operating cash flow. 
Table 2. Valuation of Sukuk on reporting dates

\begin{tabular}{llr}
\hline Item & Expected payments discounted at expected yield rates & Values \\
\hline Note 1 & $\left(6000 / 1.05+6000 / 1.05^{\wedge} 2+106000 / 1.05^{\wedge} 3\right)-100000$ & 2,723 \\
Cash Flow $_{1}$ & $-28723+7181+20000$ & $(1542)$ \\
Note 2 & $102723^{*} 0.05$ & 5,136 \\
Note 3 & $((6000 / 1.07+106000 / 1.07 \wedge 2)-102723+864)$ & $(3,667)$ \\
Cash Flow & $-17469+4367+16000$ & 2898 \\
Note 4 & $98192^{*} 0.07$ & 6,873 \\
Cash Flow & $-18756+4689+12800$ & $(1267)$ \\
Note 5 & $106000 / 1.08-98192-873$ & $(917)$ \\
Note 6 & $98148^{*} 0.08$ & 7,852 \\
Cash Flow $_{4}$ & $-18092+4253+10240$ & $(3329)$ \\
\hline
\end{tabular}

Table one showed the values for various items but not their calculations. It will easily confuse any reader how the above values are computed. Hence table two is prepared for each value computed notewise for readers to follow easily. The calculations are self-explanatory.
When the cash flow extends beyond a year the present values will be the right parameter to compare and not the total cash flows accrued. The cashflows, market yield rates at various reporting dates and the resulting present values are given in table three below.

Table 3. Internal Rate of Return and Present Values of Cash Flows

\begin{tabular}{|c|c|c|c|c|c|}
\hline & Years & Cash Flows & Yield Rates & Working & Present Values \\
\hline & 0 & $(100,000)$ & & & $(100,000)$ \\
\hline & 1 & $(1,542)$ & 0.06 & $(1542) \div 1.06$ & $(1,455)$ \\
\hline & 2 & 2,898 & 0.05 & $2898 \div 1.05^{2}$ & 2,629 \\
\hline & 3 & $(1,267)$ & 0.07 & $(1267) \div 1.07^{3}$ & $(1,034)$ \\
\hline & 4 & 96,671 & 0.08 & $96671 \div 1.08^{4}$ & 71,056 \\
\hline IRR & & $-0.82 \%$ & & & Total $(28,804)$ \\
\hline
\end{tabular}

Technically speaking there is no cash flow at all in the year 0 as the Sukukis issued straight to the supplier of machinery. But to compute the IRR in Microsoft Excel minus cash flow is needed in the current year 0. It is assumed that by issuing Sukukthe company receives cash and invest in machinery. It is opportunity cash flow. Table 3 gives negative $0.82 \%$ as internal rate of return. Minus IRR indicates that the cash out flows are less than the inflow which is highly beneficial to the borrower. The total present value is also negative meaning that cash inflow is more than the cash out flow and the borrower is benefitted by RM 28,804. There is no reduction in volatility of income as no matching profit to cancel the losses, because of higher yield rates in the third and fourth years. The company has to bear the risk of higher profit payment.

\section{Hedge Accounting}

To get the privilege of hedge accounting treatment IAS 39 puts the first condition as designation. Any company wants to apply hedge accounting must follow five rules. They are first designation of any derivative contract as the risk management item, secondly for which underlying, thirdly for what risk, fourthly the effectiveness of risk mitigation both prospectively and retrospectively, and finally which method of hedge accounting the company is willing to follow; is it cash flow or fair value hedge (Vantakeshand Vijaya,1994)?In some cases, the counter party risk also needed to be stated. Only when the above five rules are followed the company will be allowed to apply hedge accounting. 
If any of the above five rules are breached or become redundant then the hedge accounting is to be terminated retrospectively. In addition, if the prospect of the transaction is not highly probable also the hedge accounting treatment will be terminated. In other words both the underlying and hedge instrument will be treated and valued independently and any gain or loss will be expensed in income statement immediately and the underlying asset orliability with the matching derivative contract will be shown in the financial position statement at amortised costs. These methods are applicable for Islamic Finance also in total (Aaliat, 2008).

\section{Swap Contract Not Designated}

Here the company enters into a swap contract by giving up fixed profit rate and accepting floating rate. But it fails to prove hedge effectiveness prospectively and also unsure of the probability of the loss arsing for Sukuk payments. Hence it cannot apply hedge accounting and therefore the Sukuk and Swap are to be valued independently and resulting loss or profit is to be expensed in income statement and both the items are to be shown in financial position statementat amortised costs. Table four gives the valuations of both Sukuk and Swap for four years assuming that the market yield rate changes from $6 \%$ to $5 \%$, then to $7 \%$ and finally to $8 \%$ and their treatment. In addition, tablefourgives also the tax effect and finally the resulting operating cash flows.

Table 4. Valuations when informal hedge is made but swap is not designated

\begin{tabular}{|c|c|c|c|c|c|c|c|}
\hline & Cash & $\begin{array}{r}\text { Machine } \\
\text { Value }\end{array}$ & $\begin{array}{r}\text { SukukVal } \\
\text { ue }\end{array}$ & $\begin{array}{l}\text { Swap } \\
\text { Value }\end{array}$ & $\begin{array}{r}\text { Income } \\
\text { Statement }\end{array}$ & $\begin{array}{r}\text { Tax } \\
\text { Saving }\end{array}$ & $\begin{array}{l}\text { Cash } \\
\text { Flows }\end{array}$ \\
\hline \multicolumn{8}{|l|}{ Year 1} \\
\hline Buy machine by Sukuk & --- & 100,000 & $(100,000)$ & --- & --- & --- & --- \\
\hline Enter into Swap contract & --- & --- & -- & --- & --- & --- & --- \\
\hline Pay Profit & $(6,000)$ & --- & --- & --- & 6,000 & --- & --- \\
\hline \multicolumn{8}{|c|}{ Profit rate refixed at $5 \%$ on reporting date $31^{\text {st }}$ Dec } \\
\hline Revalue Sukuk - Note 1 & --- & --- & $(2,723)$ & --- & 2,723 & --- & --- \\
\hline Revalue Swap - Note 2 & --- & --- & --- & 2,723 & $(2,723)$ & --- & --- \\
\hline \multirow[t]{2}{*}{ Depreciation } & --- & $(20,000)$ & --- & --- & 20,000 & -- & --- \\
\hline & $(6,000)$ & 80,000 & $(102,723)$ & 2,723 & 26,000 & 6,500 & 500 \\
\hline \multicolumn{8}{|l|}{ Year 2} \\
\hline Pay Profit & $(6,000)$ & --- & --- & --- & 6,000 & --- & --- \\
\hline Receive Profit from dealer & 1,000 & --- & --- & --- & $(1,000)$ & --- & --- \\
\hline \multicolumn{8}{|c|}{ Profit rate refixed at $7 \%$ on reporting date $31^{\text {st }}$ Dec } \\
\hline Revalue Sukuk - Note 3 & --- & --- & 4,531 & --- & $(4,531)$ & --- & --- \\
\hline Revalue Swap - Note 4 & --- & --- & --- & $(4,531)$ & 4,531 & --- & --- \\
\hline \multirow[t]{2}{*}{ Depreciation } & --- & $(16,000)$ & --- & -- & 16,000 & --- & --- \\
\hline & $(5,000)$ & 64,000 & $(98,192)$ & $(1,808)$ & 21,000 & 5,250 & 250 \\
\hline \multicolumn{8}{|l|}{ Year 3} \\
\hline Pay Profit & $(6,000)$ & --- & --- & --- & 6,000 & --- & --- \\
\hline Pay Profit to dealer & $(1,000)$ & --- & --- & --- & 1,000 & --- & --- \\
\hline \multicolumn{8}{|c|}{ Profit rate refixed at $8 \%$ on reporting date $31^{\text {st }}$ Dec } \\
\hline Revalue Sukuk - Note 5 & --- & --- & 44 & --- & $(44)$ & --- & --- \\
\hline Revalue Swap - Note 6 & --- & --- & --- & (44) & 44 & --- & --- \\
\hline \multirow[t]{2}{*}{ Depreciation } & --- & $(12,800)$ & --- & --- & 12,800 & --- & --- \\
\hline & $(7,000)$ & 51,200 & $(98,148)$ & $(1,852)$ & 19,800 & 4,950 & $(2,050)$ \\
\hline \multicolumn{8}{|l|}{ Year 4} \\
\hline Pay Profit & $(6,000)$ & --- & --- & --- & 6,000 & --- & --- \\
\hline Pay Profit to dealer & $(2,000)$ & --- & --- & --- & 2,000 & --- & --- \\
\hline Depreciation & --- & $(10,240)$ & --- & --- & 10,240 & --- & --- \\
\hline \multirow[t]{2}{*}{ Settle all } & $(100,000)$ & --- & 100,000 & --- & --- & --- & --- \\
\hline & $(108,000)$ & 40,960 & 1,852 & $(1,852)$ & 18,240 & 4,560 & $(3,440)$ \\
\hline
\end{tabular}

Each row is a journal entry. Figures in parenthesis are credit balances. 
In the first year the market rate and the Sukuk profit rates are same hence the company does not receive or pay any excess. At the year end the market yield rate moves to $5 \%$. Both Sukuk and swap are tobe valued at this rate. The valuations are given in table five below. The debit and credit balances in the income statement will offset and profit volatility is eliminated, and income will be stable though hedge accounting is not applied. The company's net profit payments should be RM 5,000 as the market yield rate has gone down. The swap dealer will pay the resulting difference as shown in the second year of table four. Similarly, in years three and four the company has to bear the excess payments as per the market rates as it accepted the variable rate payments. The losses caused by the rate increase in Sukuk are effectively cancelled each year (RM 2,$723 ; 4,531$ and 44 ) by the swap contract in income statement though hedge accounting is not applied. This offset brings stability to income.

Table 5. Valuation of Sukuk and Swap on reporting dates

\begin{tabular}{rlr}
\hline Item & Expected payments discounted at expected yield rates & Values \\
\hline Note 1 & $-\left(6000 / 1.05+6000 / 1.05^{\wedge} 2+106000 / 1.05^{\wedge} 3\right)+100000$ & $(2,723)$ \\
Note 2 & $1000 / 1.05+1000 / 1.05^{\wedge} 2+1000 / 1.05^{\wedge} 3$ & 2,723 \\
Note 3 & $-\left(\left(6000 / 1.07+106000 / 1.07^{\wedge} 2\right)-102,723\right)$ & 4,531 \\
Note 4 & $-\left(\left(1000 / 1.07+1000 / 1.07^{\wedge} 2\right)+2,723\right)$ & $(4,531)$ \\
Note 5 & $-((106000 / 1.08)-98,192)$ & 44 \\
Note 6 & $-((2000 / 1.08)-1808)$ & $(44)$ \\
\hline
\end{tabular}

The Sukuk and swap valuation at various years are given in table five for not designated hedge.The Sukuk is valued by discounting cash flows from year two to four at market yield rate of 5\%,7\% and $8 \%$ respectively. The Swap is valued assuming that RM 1,000 cash flow regular in future years from the swap dealer and discounted at the same rate of $5 \%$. The same procedure is followed in third and fourth years but with the different yieldrates of $7 \%$ and $8 \%$ respectively. The amortised values stated at every year end for Sukuk and swap will go the financial position statement and reported accordingly. As per IAS 39 the losses and gains in the financial assets and liabilities are to be expensed in the relevant year's income statement, as such the differences in values are transferred to income statement regularly.

Table 6. Internal Rate of Return and Present Values of Cash Flows

\begin{tabular}{rrrrr}
\hline Years & Cash Flows & Yield Rates & Working & Present Values \\
\hline 0 & $(100,000)$ & & & $(100,000)$ \\
1 & 500 & 0.06 & $500 \div 1.06$ & 472 \\
2 & 250 & 0.05 & $250 \div 1.05^{2}$ & 227 \\
3 & $(2,050)$ & 0.07 & $(2050) \div 1.07^{3}$ & $(1,673)$ \\
4 & 96,560 & 0.08 & $96560 \div 1.08^{4}$ & 70,974 \\
\hline IRR & $\mathbf{- 1 . 2 1 \%}$ & & & $\mathbf{( 3 0 , 0 0 0 )}$ \\
\hline
\end{tabular}

Table six shows the operating cash flows with the notional cash inflow of RM 100,000 in the year zero. The final year cash flow is the net amount after adjusting the operating cash flow in the amount to be repaid on maturity. The IRR produced by these cash flows is equal to $-1.21 \%$ which indicates the borrower repays lesser than what he received. It is due to the different yield rates we follow in computing the Sukuk yearly payment and also while valuing Sukuk and swap. The net present value is negative RM 30,000 this is more by (30,000-28804) RM 1,196 when compared to unhedged position. Here the borrower pays 30,000 less than what he borrowed. Therefore, hedging is better than unhedged position.

\section{Fair Value Hedge And Swap Is Designated As Hedge Instrument}

IAS 39 proposes hedge accounting when certain conditions are met by companies. If the conditions are met IAS 39 allows two methods of hedge accounting fair value accounting or cash flow hedge accounting. In fair value accounting both Sukuk and swap are to be valued on all reporting dates and the 
increase or decrease are to beexpensed in income statement and the resulting swap and Sukuk values are to be shown in financial position statement in amortised costs. Table 7 shows the valuations of
Sukuk and swap on various valuation dates and the resulting gains and losses. The figures in parentheses are credit balances. For each row a journal entry could be passed.

Table 7. Valuations when fair value hedge is chosen and swap is designated

\begin{tabular}{|c|c|c|c|c|c|c|c|}
\hline & Cash & $\begin{array}{r}\text { Machine } \\
\text { Value }\end{array}$ & $\begin{array}{r}\text { SukukVal } \\
\text { ue }\end{array}$ & $\begin{array}{l}\text { Swap } \\
\text { Value }\end{array}$ & $\begin{array}{l}\text { Income } \\
\text { Statement }\end{array}$ & $\begin{array}{r}\text { Tax } \\
\text { saving }\end{array}$ & $\begin{array}{l}\text { Cash } \\
\text { Flows }\end{array}$ \\
\hline \multicolumn{8}{|l|}{ Year 1} \\
\hline Buy machine by Sukuk & --- & 100,000 & $(100,000)$ & --- & --- & --- & --- \\
\hline Enter into Swap & --- & --- & -- & --- & --- & --- & -- \\
\hline Pay Profit & $(6,000)$ & --- & --- & --- & 6,000 & --- & --- \\
\hline \multicolumn{8}{|l|}{ Profit rate refixed at $5 \%$} \\
\hline Revalue Sukuk - Note 1 & --- & --- & $(2,723)$ & --- & 2,723 & --- & -- \\
\hline Revalue Swap - Note 2 & --- & --- & -- & 2,723 & $(2,723)$ & --- & --- \\
\hline \multirow[t]{2}{*}{ Depreciation } & --- & $(20,000)$ & --- & --- & 20,000 & --- & --- \\
\hline & $(6,000)$ & 80,000 & $(102,723)$ & 2,723 & 26,000 & 6,500 & 500 \\
\hline \multicolumn{8}{|l|}{ Year 2} \\
\hline Pay Profit - Note 3 & $(6,000)$ & --- & 864 & --- & 5,136 & --- & --- \\
\hline Receive Profit from dealer & 1,000 & --- & --- & $(1,000)$ & --- & --- & --- \\
\hline Profit on Swap Note 4 & --- & --- & --- & 136 & $(136)$ & --- & --- \\
\hline \multicolumn{8}{|l|}{ Profit rate refixed at $7 \%$} \\
\hline Revalue Sukuk - Note 5 & --- & --- & 3,667 & --- & $(3,667)$ & --- & --- \\
\hline Revalue Swap - Note 6 & --- & --- & --- & $(3,667)$ & 3,667 & --- & --- \\
\hline \multirow[t]{2}{*}{ Depreciation } & --- & $(16,000)$ & --- & --- & 16,000 & --- & --- \\
\hline & $(5,000)$ & 64,000 & $(98,192)$ & $(1,808)$ & 21,000 & 5,250 & 250 \\
\hline \multicolumn{8}{|l|}{ Year 3} \\
\hline Pay Profit - Note 7 & $(6,000)$ & --- & $(873)$ & --- & 6,873 & --- & --- \\
\hline Pay Profit to dealer & $(1,000)$ & --- & -- & 1,000 & --- & --- & --- \\
\hline Profit on Swap Note 8 & -- & --- & -- & $(127)$ & 127 & --- & -- \\
\hline \multicolumn{8}{|l|}{ Profit rate refixed at $8 \%$} \\
\hline Revalue Sukuk - Note 9 & --- & --- & 918 & --- & (918) & --- & --- \\
\hline Revalue Swap - Note 10 & --- & --- & --- & (918) & 918 & --- & -- \\
\hline \multirow[t]{2}{*}{ Depreciation } & --- & $(12,800)$ & --- & -- & 12,800 & --- & --- \\
\hline & $(7,000)$ & 51,200 & $(98,148)$ & $(1,852)$ & 19,800 & 4,950 & $(2,050)$ \\
\hline \multicolumn{8}{|l|}{ Year 4} \\
\hline Pay Profit - Note 11 & $(6,000)$ & --- & $(1,852)$ & --- & 7,852 & --- & --- \\
\hline Pay Profit to dealer & $(2,000)$ & --- & -- & 2,000 & -- & --- & -- \\
\hline Profit on swap Note 12 & --- & --- & --- & (148) & 148 & --- & --- \\
\hline Depreciation & --- & $(10,240)$ & --- & -- & 10,240 & --- & --- \\
\hline Settle all & $(100,000)$ & --- & 100,000 & --- & --- & --- & --- \\
\hline Total & $(108,000)$ & 40,960 & - & - & 18,240 & 4,560 & $(3,440)$ \\
\hline
\end{tabular}

Each row is a journal entry. Figures in parenthesis are credit balances.

Table seven shows the valuations of Sukuk and swap on various reporting dates. The same rules and procedures are followed as in the previous no designated hedge. The differences in valuations are be expensed in income statement as when they arise. The only difference is the valuation of swap is bit different. Here the swap also will get regular income in the form of profit at the prevailing market yield rate and this amount is also to be expensed in income statement regularly. The swap profit computed is credited to income when the rates are favourable as gain and vice versa.

Though the end results are same for both not designated swap and designated swap the valuations and profit paid are treated differently. For instance, in the second year the profit paid RM 6,000 is not debited fully but only RM5,136. The remaining amount RM 864 is debited in Sukuk value. The profit received from swap dealer due to rate drop is not debited to income statement rather it is credited to swap contract. Similarly, the profit paid 
to swap dealer in year3 and year 4 are treated but in the opposite way as the rates go up from $6 \%$ to $7 \%$ and $8 \%$ respectively.

Table 8. Valuation of Sukuk and Swap on reporting dates for fair value hedge

\begin{tabular}{llr}
\hline Item & Expected payments discounted at expected yield rates & Values \\
\hline Note 1 & $\left(6000 / 1.05+6000 / 1.05^{\wedge} 2+106000 / 1.05^{\wedge} 3\right)-100000$ & 2,723 \\
Note 2 & $1000 / 1.05+1000 / 1.05^{\wedge} 2+1000 / 1.05^{\wedge} 3$ & 2,723 \\
Cash Flow 1 & $-26000+6500+20000$ & 500 \\
Note 3 & $102723^{*} 0.05$ & 5,136 \\
Note 4 & $2723^{*} 0.05$ & 136 \\
Note 5 & $\left(6000 / 1.07+106000 / 1.07^{\wedge} 2\right)-102723+864$ & $(3,667)$ \\
Note 6 & $1000 / 1.07+1000 / 1.07^{\wedge} 2+2723+136-1000$ & 3,667 \\
Cash Flow & $-21000+5250+16000$ & 250 \\
Note 7 & $98192^{*} 0.07$ & 6,873 \\
Note 8 & $1808^{*} 0.07$ & 127 \\
Note 9 & $(106000 / 1.08)-98192-873$ & $(917)$ \\
Note 10 & $(2000 / 1.08)+1808+127-1000$ & $2,786.9$ \\
Cash Flow & $-19800+4950+12800$ & $(2,050)$ \\
Note 11 & $98148^{*} 0.08$ & 7,852 \\
Note 12 & $1852^{*} 0.08$ & 148 \\
Cash Flow & $-18240+4560+10240$ & $(3,440)$ \\
\hline
\end{tabular}

The readers will be easily confused how the values presented in table seven are arrived at. Hence table eight is prepared for illustrative purpose and shown above.

Table 9. Internal Rate of Return and Present Values of Cash Flows

\begin{tabular}{rrrr}
\hline Years & Cash Flows & Yield Rates & Present Values \\
\hline 0 & $(100,000)$ & & $(100,000)$ \\
1 & 500 & 0.06 & 472 \\
2 & 250 & 0.05 & 227 \\
3 & $(2,050)$ & 0.07 & $(1,673)$ \\
4 & 96,560 & 0.08 & 70,974 \\
\hline IRR & $\mathbf{- 1 . 2 1 \%}$ & & $\mathbf{( 3 0 , 0 0 0 )}$ \\
\hline
\end{tabular}

Table nine is absolutely the same as table six as the income statement reveals the same income as in the not designated hedge. The fair value hedge produces the same IRR and negative net present value indicating the company (borrower) repay less than what it received. This is due to the higher yield rate we apply in the later years to discount the cash flows as the discount rates and the cash flows are negatively related. During the decreasing yield rate periods the company may have to repay more.

\section{Cash Flow Hedge And Swap Is Designated As Hedge Instrument}

The cash flow hedge is a unique hedge which mandates that the swap only to be valued and not the
Sukuk. The value of swap contract also not to be expensed in income statement instead it is to be accumulated in equity that is in the other comprehensive income (OCI). Finally, on the maturity the value of swap will be reclassified as income from OCI. It is cookie jar technique to smooth the income. When gains accrue increase the equity when losses incurred in swap decrease the equity and finally reclassify as income. But there is an exception to this rule. If the expected losses are not highly probable in future,then the equity is to be reclassified as income immediately. In addition to meet the matching principle an equal amount like the change in Sukukvalue will be reclassified from OCI at every reporting date and stated as income or loss in the income statement. 
The highly challenging item in the cash flow hedge is to track the hedged item whether it causes impact in profits. If it affects the amount in OCI is to be reclassified as income and to be reported in income statement. This will be challenging if raw materials are procured by a holding company and if transfers to its subsidiaries which are producing multiple products and so on. But in fair value hedge this tracking down is not needed as the valuation differences are not adjusted in OCI but in income statement straight away. Therefore, fair value hedge is simple and bit easier when compared to cash flow hedge.

Table 10 shows the valuations and their treatments in accounting when cash flow hedge is chosen. As usual each row is one journal and the figures appear in parenthesis are credit balances. The Sukuk is always shown in par value and not valued at reporting dates. ButSukuk is valued indirectly; it is to be valued to track whether it impacts the income or not because some portion of the equity is to be reclassified and that portion of equity reclassified is to be expressed in income statement in every reporting date.Else it will violate the matching principle of accounting.

\section{ISSN 2455-6378}

Unlike in fair value hedge the profit paid RM 6,000 to Sukuk holders directly stated in income statement at all reporting periods. The swap is valued at every reporting date including the profit attributable to swap and stated in OCI and not shown in income statement. In every reporting date the difference in Sukuk profit paid to the Sukuk holders is transferred from equity to income statement to fulfil the matching principle. In the second year the company receives a profit of RM 1,000 as the market yield rates drops from $6 \%$ to $5 \%$. From equity this RM 1,000 is transferred as credit balance in equity and this will smooth the volatility in income. In the third year the rate goes to $7 \%$ an increase of $1 \%$ from the reference rate and it is paid by the company to the swap dealer. This amount is reclassified as loss from equity and reported in income statement as debit balance. Similarly, in the fourth year RM 2,000 is paid by the company to swap dealer as the market yield rate went up to $8 \%$ from $6 \%$. This amount is reclassified from equity to income statement in the fourth year. This mechanism of reclassification brings the smoothing effect to incomes which in turn reduce the volatility. In the final year both the Sukuk and swap become nil as they are settled without causing any massive profit or loss transferred to income statement from these accounts. Everything moves and within the limits.

Table 10. Valuations when cash flow value hedge is chosen and swap is designated

\begin{tabular}{|c|c|c|c|c|c|c|c|c|}
\hline & Cash & $\begin{array}{r}\text { Machine } \\
\text { Value }\end{array}$ & $\begin{array}{r}\text { SukukValu } \\
\mathrm{e}\end{array}$ & $\begin{array}{l}\text { Swap } \\
\text { Value }\end{array}$ & $\begin{array}{r}\mathrm{OCl} \\
\text { Equity }\end{array}$ & $\begin{array}{r}\text { Income } \\
\text { Statement }\end{array}$ & $\begin{array}{r}\text { Tax } \\
\text { saving }\end{array}$ & $\begin{array}{l}\text { Cash } \\
\text { Flows }\end{array}$ \\
\hline \multicolumn{9}{|l|}{ Year1 } \\
\hline Buy machine & --- & 100,000 & $(100,000)$ & --- & --- & --- & --- & --- \\
\hline Enter into Swap & --- & --- & --- & --- & --- & --- & --- & --- \\
\hline Pay Profit & $(6,000)$ & --- & --- & --- & --- & 6,000 & --- & --- \\
\hline Receive Profit & --- & --- & --- & --- & --- & --- & --- & --- \\
\hline \multicolumn{9}{|l|}{$\begin{array}{l}\text { Profit rate refixed at } \\
5 \%\end{array}$} \\
\hline Revalue Swap - Note 1 & --- & --- & --- & 2,723 & $(2,723)$ & --- & --- & --- \\
\hline \multirow[t]{2}{*}{ Depreciation } & --- & $(20,000)$ & --- & --- & & 20,000 & --- & --- \\
\hline & $(6,000)$ & 80,000 & $(100,000)$ & 2,723 & $(2,723)$ & 26,000 & 6,500 & 500 \\
\hline \multicolumn{9}{|l|}{ Year 2} \\
\hline Pay Profit & $(6,000)$ & --- & & --- & --- & 6,000 & --- & --- \\
\hline Receive Profit & 1,000 & --- & --- & $(1,000)$ & --- & --- & --- & --- \\
\hline Profit on Swap Note 2 & --- & --- & --- & 136 & $(136)$ & --- & --- & --- \\
\hline \multicolumn{9}{|l|}{$\begin{array}{l}\text { Profit rate refixed at } \\
7 \%\end{array}$} \\
\hline Reclassify Equity & --- & --- & --- & --- & 1,000 & $(1,000)$ & --- & --- \\
\hline Revalue Swap - Note 3 & --- & --- & --- & $(3,667)$ & 3,667 & --- & --- & --- \\
\hline \multirow[t]{2}{*}{ Depreciation } & --- & $(16,000)$ & --- & --- & --- & 16,000 & --- & --- \\
\hline & $(5,000)$ & 64,000 & $(100,000)$ & $(1,808)$ & 1,808 & 21,000 & 5,250 & 250 \\
\hline
\end{tabular}




\begin{tabular}{|c|c|c|c|c|c|c|c|c|}
\hline \multirow{2}{*}{\multicolumn{2}{|c|}{ Year 3}} & \multirow[b]{3}{*}{--- } & \multirow[b]{3}{*}{---} & \multirow[b]{3}{*}{--} & \multirow[b]{3}{*}{--- } & \\
\hline & & & & & & & & \\
\hline Pay Profit & $(6,000)$ & & & & & 6,000 & --- & --- \\
\hline Pay Profit & $(1,000)$ & --- & --- & 1,000 & --- & --- & --- & --- \\
\hline Profit on Swap Note 4 & --- & --- & --- & (127) & 127 & --- & --- & --- \\
\hline \multicolumn{9}{|l|}{$\begin{array}{l}\text { Profit rate refixed at } \\
8 \%\end{array}$} \\
\hline Reclassify Equity & --- & --- & --- & --- & $(1,000)$ & 1,000 & --- & --- \\
\hline Revalue Swap - Note 5 & --- & --- & --- & (918) & 918 & --- & --- & --- \\
\hline \multirow[t]{2}{*}{ Depreciation } & --- & $(12,800)$ & --- & --- & --- & 12,800 & --- & --- \\
\hline & $(7,000)$ & 51,200 & $(100,000)$ & $(1,852)$ & 1852 & 19,800 & 4,950 & $(2,050)$ \\
\hline \multicolumn{9}{|l|}{ Year 4} \\
\hline Pay Profit & $(6,000)$ & --- & & --- & --- & 6,000 & --- & --- \\
\hline Pay Profit & $(2,000)$ & --- & --- & 2,000 & --- & --- & --- & --- \\
\hline Profit on swap Note 6 & --- & --- & --- & (148) & 148 & --- & --- & -- \\
\hline Reclassify Equity & --- & --- & --- & --- & $(2,000)$ & 2,000 & & \\
\hline Depreciation & --- & $(10,240)$ & --- & --- & --- & 10,240 & --- & --- \\
\hline \multirow[t]{2}{*}{ Settle all } & $(100,000)$ & --- & 100,000 & --- & --- & --- & --- & --- \\
\hline & $(108,000)$ & 40,960 & - & - & - & 18,240 & 4,560 & $(3,440)$ \\
\hline
\end{tabular}

Each row is a journal entry. Figures in parenthesis are credits.

The valuation figures may surprise some readers as how they have been arrived at. Table 10 shows the calculations year wise. These calculations are similar to fair value accounting. Only the swap is valued but not the Sukuk as it is a cash flow hedge.

Table 11. Valuation of Swap on reporting dates

\begin{tabular}{llr}
\hline Item & Expected payments discounted at expected yield rates & Values \\
\hline Note 1 & $1000 / 1.05+1000 / 1.05^{\wedge} 2+1000 / 1.05^{\wedge} 3$ & 2,723 \\
Note 2 & $2723^{*} 0.05$ & 136 \\
Note 3 & $1000 / 1.07+1000 / 1.07^{\wedge} 2+2723+136-1000$ & 3,667 \\
Note 4 & $1808^{*} 0.07$ & 127 \\
Note 5 & $(2000 / 1.08)-1808-127+1000$ & 917 \\
Note 6 & $1852^{*} 0.08$ & 148 \\
\hline
\end{tabular}

Table 11 is absolutely the same as table 8 as the income statement reveals the same income as in the not designated hedge. The fair value hedge produces the same IRR and negative net present value indicating the company (borrower) repay less than what it received. This is due to the higher yield rate we apply in the later years to discount the cash flows as the discount rates and the cash flows are negatively related. During the decreasing yield rate periods the company may have to repay more.

Table 12. Internal Rate of Return and Present Values of Cash Flows

\begin{tabular}{rrrr}
\hline Years & Cash Flows & Yield Rates & Present Values \\
\hline 0 & $(100,000)$ & & $(100,000)$ \\
1 & 500 & 0.06 & 472 \\
2 & 250 & 0.05 & 227 \\
3 & $(2,050)$ & 0.07 & $(1,673)$ \\
4 & 96,560 & 0.08 & 70,974 \\
\hline IRR & $\mathbf{- 1 . 2 1 \%}$ & & $\mathbf{( 3 0 , 0 0 0 )}$ \\
\hline
\end{tabular}


Table 12shows the same minus IRR as in not designated hedge and fairvalue hedge. Though the valuations and accounting treatments are different they converge finally to the same profits and same tax shields and same cash flows producing same IRR and net present values.
The above results show that not designated hedge, fair value hedge and cash flow hedge follow different accounting rules, but they all converge ultimately to the same results. But the unhedged position differs significantly. Their profit or loss position is given in table 13 for easy comparison.

Table 13. Losses after tax and standard deviations of various types of hedges

\begin{tabular}{lrrrr}
\hline & No Hedge & Not designated & Fair Value & Cash flow \\
\hline Year1 & 28723 & 26000 & 26000 & 26000 \\
Year2 & 17469 & 21000 & 21000 & 21000 \\
Year3 & 18756 & 19800 & 19800 & 19800 \\
Year4 & 18092 & 18240 & 18240 & 18240 \\
\hline Mean & 20760 & 21260 & 21260 & 21260 \\
Std Dev & 4620 & 2906 & 2906 & 2906 \\
\hline
\end{tabular}

The mean loss is RM 20,760 for unhedged position whereas the hedged positions show higher mean lossesof RM 21,260, which is greater by RM 500 . This may differ if the market yield rates change differently. The standard deviation of losses for the unhedged position is RM 4,620, while hedged position it is RM 2,906 lesser by RM 1,714. This is the smoothing effect in volatility of profits.

\section{Conclusions}

Hedge accounting is a challenging topic to understand. In Islamic finance the derivative products are emerging fast but matching, valuing and treating them in accounting are all new. Even experienced accountants sometimes baffled to value and treat them correctly in income statement or in OCI and financial position statement. A clear valuation and treatment illustration throws more light and clears several ambiguities. It is found out that only unhedged position differs substantially from hedged positions. The hedged positions, all produce the same results and may not be important in hedge accounting. Among the hedged positions the not designated, fair value and cash flow do not differ in the outcomes though they are treated differently in income and financial position statements. The hedge accounting is special accounting treatment available for companies who follow strictly the matching, documenting and effectiveness proving both prospectively and retrospectively. In this article effectiveness is hundred percentages hence it is not demonstrated. If any of the conditions fail, then the hedge accounting will be withdrawn and the not designated treatment is to be followed for both Sukuk and swap contracts. Since the results are same for the three hedging methods any company wants to follow hedging can proceed confidently under any method as the results are same for all methods in reducing volatility in income.This volatility reduction is beneficial to several stakeholders like shareholders, Sukuk Issuers, and regulators.

\section{References}

[1] Aaliat al-Tahawwuth fi al-Amaliyat alMaliyah al-Islamiah Shari`a, (2008), Standards for Islamic Financial Institutions Accounting and Auditing Organization for Islamic Financial Institutions (AAOIFI), Bahrain.

[2] Abken, P. (1993) Valuation of defaultriskyinterest-rate swaps, Advances in Futures andOptions Research 6, 93-116.

[3] Al-Suwailem, Sami (2006), "Hedging in Islamic Finance," Islamic Development Bank: Occasional Paper no.10.

[4] Bacha, Obiyathulla I., 2007, Financial Derivatives: Markets and Applications in Malaysia, $2^{\text {nd }}$ ed. Malaysia: McGraw-Hill.

[5] Brown, K., Harlow, W., and Smith, D. (1994) Anempirical analysis of interest rate swap spreads, The Journal of Fixed Income 4, 61-78.

[6] Coyle, Bryan, (2000),Hedging Currency Exposure, United Kingdom: Financial World Publishing. 
[7] Coyle, Bryan, (2001),Interest Rate Swap, United Kingdom: Financial World Publishing.

[8] Das, Satyajit (1994) Swaps and Financial Derivatives: The Global Reference to Products, Pricing, Applications, and Markets, 2nd ed., The Law Book Company, Sydney.

[9] Decovny, Sherree and Christine Racchi. (1991) Hedging Strategies. Cambridge.

[10] Hussain Hamid Hassan (2009), Basic Sharia Principles Governing Risk Management, paper presented in Harvard-LSE Workshop on Risk Management. London School of Economics

[11] Kijima, M., \&Muromachi, Y., (2001), PricingEquity Swaps in a Stochastic Interest RateEconomy, The Journal of Derivatives, 8, 19-35.

[12] Marshal, John and Kenneth Kapner, (1990),The Swaps Handbook, New York: New York Institute of Finance.
[13] Sawyer, Nick, (2006), Islamic Finance: SpecialReport. Risk, Vol. 19 Issue 9, p9595.

[14] Vantakesh, Raj and Vijaya Vantakesh (1994), Interest Rate and Currency Swaps: The Market Products and Application, Chicago: Probus Publishing.

[15] Wardrep, B. N. and J. F. Buck, "The Efficacy of Hedging with Financial Futures: An Historical Perspective," Journal of Futures Markets, vol.2.

[16] Woodhead-Faulkner; 2009, International Conference on Islamic Perspectives on Management and Finance; University of Leicester.

[17] Yahya, Ahmad Suhaimi. (2008), Hedging Mechanism in Islamic Finance from the Perspective of Shariah. Presented in the Third Islamic Finance Sharah Advisors 